\title{
UPAYA KEPOLISIAN DALAM PENANGGULANGAN TINDAK PIDANA KEKERASAN YANG DILAKUKAN PELAJAR (Studi wilayah hukum polres Dompu)
}

\author{
Neneng Anggraeni' ${ }^{1}$ Zaini Bidaya²
}

${ }^{1}$ Pendidikan Pancasila dan Kewarganegaraan, Universitas Muhammadiyah Mataram, nenenganggraeni12gmail.com ${ }^{2}$ Pendidikan Pancasila dan Kewarganegaraan, Universitas Muhammadiyah Mataram, zainibidaya@gmail.com

\begin{tabular}{l} 
INFO ARTIKEL \\
\hline Riwayat Artikel: \\
Diterima: $\quad$ 05-Februari- \\
2018 \\
Disetujui: $10-M a r e t-2018$
\end{tabular}

Kata Kunci:

Penanggulangan

Tindak Pidana

Pelajar

\section{A. LATAR BELAKANG}

Anak atau pelajar adalah bagian dari generasi muda sebagai salah satu sumber daya manusia yang merupakan potensi dan penerus cita-cita perjuangan bangsa, yang memiliki peranan strategis dan mempunyai ciri dan sifat khusus, memerlukan

\begin{abstract}
Abstrak: Peristiwa kenakalan anak-anak yang mengarah kepada tindak pidana kekerasan yang terjadi di Dompu yang berupa kekerasan fisik seperti memukul, menendang, menjambak dan lain-lain. Penegak hukum yang berwenang dalam hal ini adalah polisi mempunyai peran dan tanggung jawab menurut Undang-undang No.2 tahun 2002 tentang Kepolisian Negara Republik Indonesia Pasal 13 mengatakan bahwa tugas pokok Kepolisian Negara Republik Indonesia adalah Memelihara keamanan dan ketertiban masyarakat. Penegakan hukum dan Memberikan perlindungan, pengayoman, dan pelayanan kepada masyarakat. Tujuan penelitian ini yaitu untuk mengetahui upaya kepolisian dalam penanggulangan tindak pidana kekerasan yang dilakukan oleh pelajar dan untuk mengetahui kendala yang dihadapikepolisian dalam menangani masalah tindak pidana kekerasan yang dilakukan oleh pelajar di Dompu. Metode penelitian menggunakan metode hukum empiris, dengan pendekatan sosiologis hukum. Tehnik pengumpulan data digunakan yaitu, observasi, wawancara dan dokumentasi. Penelitian ini dilakukan di polres Dompu. Tehnik analisis data di bagi menjadi tiga yaitu, reduksi data, penyajian data, dan menarik kesimpulan. Berdasarkan uraian hasil penelitian dan hasil data, dapat disimpulkan bahwa upaya kepolisian dalam penanggulangan tindak pidana kekerasan yang dilakukan oleh pelajar di Dompu, yaitu melakukan penyuluhan-penyuluhan, disetiap sekolah maupun desadesa, melakukan kerja sama dengan berbagai komponen atau lembaga yang berkaitan,sedangakn kendala yang dihadapi kepolisian, yaitu pelaku bungkam,Balai Pemasyarakatan (BAPAS) dan orang tua.
\end{abstract}

\begin{abstract}
Children's mischief events that lead to criminal acts of violence that occurred in Dompu in the form of physical violence such as hitting, kicking, grabbing and others. The law enforcer in this case is that the police have roles and responsibilities according to Law No. 2 of 2002 concerning the National Police of the Republic of Indonesia Article 13 states that the main task of the National Police of the Republic of Indonesia is to maintain security and public order. Law enforcement and providing protection, protection and service to the community. The purpose of this study is to find out the police efforts in the handling of criminal acts of violence committed by students and to find out the obstacles faced by the police in handling the problem of criminal acts of violence committed by students in Dompu. The research method uses empirical legal methods, with a sociological legal approach. Data collection techniques are used, namely, observation, interviews and documentation. This research was conducted at Dompu police station. Data analysis techniques are divided into three, namely, data reduction, data presentation, and drawing conclusions. Based on the description of the results of the study and the results of the data, it can be concluded that the police effort in the handling of criminal acts of violence committed by students in Dompu, namely conducting counseling, in each school and villages, conducted cooperation with various related components or institutions, while obstacles faced by the police, namely the perpetrators of silence, the Correctional Center (BAPAS) and parents.
\end{abstract}

pembinaan dan pengarahan dalam rangka menjamin pertumbuhan dan perkembangan fisik, mental dan sosial secara utuh serasi, selaras, dan seimbang. Untuk melaksanakan pembinaan dan memberikan perlindungan terhadap anak diperlukan dukungan, baik yang menyangkut kelembagaan maupun perangkat hukum yang lebih mantap dan memadai. 
Peristiwa kenakalan anak-anak yang mengarah kepada tindak pidana kekerasan yangterjadi di Dompu yang berupa kekerasan fisik seperti memukul, menendang, menjambak dan lain-lain. Selain bullying, kekerasan antar siswa yang sering terjadi adalah tawuran. Selain kekerasan fisik juga terjadi kekerasan verbal seperti mengejek, menghina atau mengucapkan kata-kata yang menyinggung atau membuat cerita bohong yang menyebabkan siswa yang menjadi sasaran menjadi terkucilkan atau menjadi bahanolok-olok sehinggsa iswa yang bersangkutan menjadi rendah diri, takut dan sebagainya.

Menurut Moeljatno, (2015 : 59) menjelaskan perbuatan pidana merupakan "Perbuatan pidana adalah perbuatan yang dilarang oleh suatu aturan hukum larangan mana disertai ancaman (sanksi) yang berupa pidana tertentu, bagi barang siapa yang melanggar larangan tersebut. Dapat juga dikatakan bahwa perbuatan pidana adalah perbuatan yang oleh suatu aturan hukum dilarang dan diancam pidana, asal saja dalam pada itu diingat bahwa larangan ditujukan kepada perbuatan (yaitu suatu keadaan atau kejadian yang ditimbulkan oleh kelakuan orang), sedangkan ancaman pidananya ditujukan kepada orang yang menimbulkan kejadian itu."

Istilah tindak pidana atau dalam bahasa belanda, strafbaar feit,yang sebenarnya merupakan istilah resmi dalam strafwetboek atau kitab Undang-Undang Hukum pidana, yang sekarang berlaku di Indonesia. Ada istilah dalam bahasa asing, yaitu delict. Secara harfiah tindak pidana (strafbaarfeit), berasal dari dua kata yaitu stafbaaryang berarti hukum, dan feityang berarti sebagian suatu kenyataan yang dapat dihukum (P.A.F. Lamintang, 2002 :181). Sedangkan menurut pembentukan perundang-undang kata perkataan strafbaarfeituntuk menyebutkan tindak pidana sebagaimana yang kita kenal dan yang ada dalam KUHP tanpa memberikan suatu penjelasan mengenai apa sebenarnya. Jadi umumnya tindak pidana merupakan suatu perbuatan yang melanggar hukum, dan bertentangan dengan peraturan perundang-undangan yang berlaku.

Menurut Moeljatno, (2015:64) unsur-unsur tindak pidana pada Hakikatnya, setiap perbuatan pidana harus terdiri dari Unsur-unsur lahiriah (fakta) oleh perbuatan, mengandung kelakuan dan akibat yang ditimbulkan karenanya.Keduanya memunculkan kejadian dalam alam lahir (dunia). Maka yang merupakan unsur atau elemen perbuatan pidana adalah :

1. Kelakuan dan akibat, untuk adanya perbuatan pidana biasanya diperlukan pula adanya

2. Hal ikhwal atau keadaan tertentu yang menyertaiperbuatan.

3. Keadaantambahan yang memberatkanpidana.

4. Unsurmelawan hokum obyektifadalahunsur-unsur yang adahubungannyadengankeadaan-keadaan, yaitu di dalamkeadaan-keadaanmanatindakantindakandarisi pelaku itu harus dilakukan.

5. Unsur melawan hukum subjektif adalah unsurunsur yang melekat pada diri si pelaku atau yang berhubungan dengan diri si pelaku, dan termasuk ke dalamnya yaitu segala sesuatu yang terkandung di dalam hatinya."

Berbagai tindak pidana diatas, diperlukan pencegahan agar perilaku kejahatan tersebut tidak terjadi lagi di masa mendatang. Maka berdasarkan hasil riset kami ini, mencoba menuliskan upaya kepolisian dalam penanggulangan tindak pidana kekerasan yang dilakukan pelajar. Karena hasil riset kami ini penting disampaikan.

Penegak hukum yang berwenang dalam hal ini adalah polisi mempunyai peran dan tanggung jawab menurut Undang-undang No.2 tahun 2002 tentang Kepolisian Negara Republik Indonesia Pasal 13 mengatakan bahwa tugas pokok Kepolisian Negara Republik Indonesia adalah memelihara keamanan dan ketertiban masyarakat, menegakan hokum dan memberikan perlindungan, pengayoman, dan pelayanan kepada masyarakat.

Menjalankan tugas dan fungsinya sebagai penegak hukum Kepolisian dapat bertindak secara preventif maupun represif. Dengan adanya tindakan dari kepolisian ini diharapkan dapat memberikan pengarahan kepada remaja maupun anak-anak yang belum melakukan tindak pidana dan memberikan efek jera terhadap anak yang sudah melakukan tindak pidana, walaupun demikian penanganan kasus tindak pidana yang dilakukan oleh anak tidaklah sama seperti penanganan kasus tindak pidana yang dilakukan oleh orang dewasa, pihak penegak hukum harus tetap memperhatikan kondisi fisik maupun mental anak tersebut karena bagaimanapun anak adalah generasi penerus bangsa.

Dengan demikian upaya penaggulangan kejahatan secara garis besar dapat dibagi dua, yaitu lewat jalur penal (hukum pidana) dan lewat jalur non penal (bukan/diluar hukum pidana). Dalam pembagian G.P Hoefnagels tersebut diatas upaya-upaya disebut dalam (b) dan (c) dapat dimasukkan dalam kelompok upaya non penal. Secara kasar dapatlah dibedakan, bahwa upaya penaggulanagan kejahatan lewat jalur penal lebih menitikberatkan pada sifat preventif sebelum kejahatan terjadi[1].

Sebagaimana diatur dalam Undang-undangNomor 2 Tahun 2002 tentang kepolisian Negara Republik Indonesia Pasal 13 mengatakan bahwa tugas pokok Kepolisian Negara Republik Indonesia adalah 1) memeliharan keamanan dan ketertibab masyarakat, 2) menegakkan hukum danMemberikan perlindungan, pengayoman, dan pelayanan kepada masyarakat [2].

Tujuan penelitian ini yaitu untuk mengetahui upaya kepolisian dalam penanggulangan tindak pidana kekerasan yang dilakukan oleh pelajar dan untuk 
mengetahui kendala yang dihadapikepolisian dalam menangani masalah tindak pidana kekerasan yang dilakukan oleh pelajar di Dompu.

\section{B. METODE PENELITIAN}

Metode penelitian ini menggunakan penelitian hukum empiris, hukum dikonsepkan sebagai pranata sosial yang secara riil dikaitkan variabel-variabel sosial yang lain. Apabila hukum sebagai gejala sosial yang empiris sifatnya,dikaji sebagai variabel bebas/sebab (independen variabel) yang menimbulkan pengaruh dan akibat pada berbagai aspek kehidupan sosial,kajian ini merupakan kajian hukum yang sosiologis (sociolegal resect) namun, jika hukum dikaji sebagai variabel tergantug atau akibat (independen variabel) yang timbul sebagai hasil dari berbagai kekuatan dalam proses sosial, kajian itu merupakan kajian sosiologis hukum (sosiology of law).

Penelitian hukum empiris yaitu untuk mengamati bagaimana fakta yang terjadi di lapangan atau dalam masyarakat, sehingga peneliti dapat mempermudah untuk mendapatkan data-data di lapangan sesuai dengan harapan dalam penelitian.

Yang menjadi subjek utama dan pertama dalam penelitian kasus ini adalah pihak yang bersangkutan yaitu Kasat reskrim Dompu, bagian penyidik, anggota kepolisian, pelajar atau anak yang ada di wilayah hukum Polres Dompu.

Teknik pengumpulan data dilakukan dengan tiga cara yaitu:

1. Metode observasi.

Observasi menjadi observasi berpartisipasi (participant obsevation),observasi yang secara terang-terangan dan tersamar (overt observation dan covert observation), dan observasi yang tak berstruktur (unstruktur observation)[3];[4].

2. Metode wawancara (interview)

Beberapa macam-macam wawancara, dari yaitu, wawancara terstruktur, wawancara Semiterstruktur dan wawancara tidak terstruktur[5];[4]. Oleh karena itu, dalam hal ini peneliti mengambil metode wawancara yang terstruktur dimana peneliti telah mengetahui dengan pasti tentang informasi apa yang akan diperoleh. Oleh karena itu dalam melakukan wawancara, pengumpul data telah menyiapkan instrumen penelitian berupa pertanyaan tertulis yang alternatif jawabanya pun telah disiapkan. Dengan wawancara terstruktur ini setiap responden diberi pertanyaan yang sama, dan pengumpulan data mencatatnya

3. Metode Dokumentasi

Metode dokumentasi, yaitumencari data mengenai hal-hal atau variabel yang berupa catatan, tanskrip, buku, surat kabar, majalah, prasasti, notulen rapat, lengger, agenda,dan sebagainya[6].

Kemudian analisis data menggunakan deskriptif analitis untuk menguraikan data lapangan dengan studi literatur dengan pendekatan perundang-undangan dan pendekatan konseptual.

\section{HASIL DAN PEMBAHASAN}

1. Upaya Kepolisian Dalam Penanggulangan Tindak Pidana Kekerasan yang dilakukan oleh Pelajar di dompu.

Berdasarkan hasil wawancara dengan Bapak AKP Daniel Partogi Simanguncong, selaku Kasat Sat Res Kriminal Polres Dompu pada tanggal 15 mei 2017 bahwa upaya-upaya yang telah dilakukan oleh Polres Dompu untuk menanggulangi tindak pidana kekerasan yang dilakukan oleh pelajar di Kabupaten Dompu berikut:

"Melakukan penyuluhan-penyuluhan yang dilakukan di sekolah-sekolah, kantor Desa dan Kecamatan ditujukan kepada warga desa atau Kecamatan yang secara khusus adalah kepada anak pelajar dan remaja dan juga kepada Karang taruna yang beranggotakan para pemuda dan anak pelajar di desa atau kecamatan setempat maupun di Instansi pemerintahan untuk memberikan pemahaman tentang apa itu tindak pidana kekerasan dan sanksi hukum yang akan dijatuhkan apabila melakukan tindak pidana kekerasan.pemberian pemahaman ini bertujuan agar anak pelajar atau remaja tidak melakukan tindak pidana kekerasan dan tahu akan bahaya yang ditimbulkan apabila melakukan tindak pidana kekerasan.dengan dilakukan penyuluhan ini diharapkan masyarakat khususnya anak pealajar dan remaja dapat ikut serta berpartisipasi dalam membantu memberantas tindak pidana kekerasan dengan cara menghindari perbuatan melakukan kekerasan serta jika ditemukan atau mengalami suatu tindak pidana kekerasan oleh pelajar segera melaporkan kepada pihak kepolisian tentang adanya tindak pidana kekerasan yang dilakukan oleh pelajar".

Ia juga menambahkan tentang kerjasama dnegan lembaga lain dalam melakukan pencegahan, berikut pernyataannya:

"Melakukan kerja sama dengan berbagai komponen antara lain Lembaga Pembinaan Khusus Anak, Lembaga Penempatan Anak Sementara, Lembaga Penyelenggaraan Kesejahteraan Sosial, Balai Pemasyarakatan, dan Instansi-instansi lain yang terkait".

Sementara kapolres menyatakan bahwa

"Upaya pencegahan yang dilakukan

KepolisianResort Dompu seperti melakukan patroli, pengawasan oleh babinsa yang dibantu oleh masyarakat dalam hal melakukan ronda malam mencari anak-anak pelajar yang suka melakukan tindak pidana kekerasan seperti di jalan raya, ditempat keramaian atau acaraacara malam seperti orkestra ataupun di Lapangan terbuka tempat mereka janjian untuk berkelahi".

Jadi kepolisian Resort Dompu dalam menanggulangi tindak Pidana kekerasan yang dilakukan oleh pelajar di 
Kabupaten Dompu, Upaya Represif merupakan upaya penindakan[7].

Upaya Kepolisian dalam Penaggulangan tindak pidana kekerasan yang dilakukan oleh pelajar,sangat banyak penanggulangan yang dilakukan oleh kepolisian seperti melakukan penyeluhan-penyeluhan disetiap sekolah mengadakan patroli, ronda malam serta kepolisian melakukan kerja sama dengan pihak atau lembaga yang besangkutan sehinnga penanggulangan yang dilakukan oleh kepolisian sangat baik dalam menanggulangi tindak pidana yang dilakukan oleh pelajar di Dompu.

2. Faktor yang menyebabkan anak melakukan tindak pidana kekerasan

Adapun beberapa faktor yang menyebabkan Pelajar ini melakukan Tindak Pidana kekerasan antara lain :

"Lingkungan, dimana lingkungan yang saya tinggali itu sangat rawan melakukan tindak pidana kekersan. Keluarga, kurang nya pengawasan darikeluarga saya. (wawancara dengan Anas, Andika, dan Wendy 22 Mei 2017)”

Selain itu, data hasil penelitian menunjukkan tindakan pidana seksual yang dilakukan anak sangat tidak etis, berikut keterangannya

"Dan anak lainnya pun memberikan alasan dia melakukan pencabulan karena rasa ingin tahu saya terhadap cewek itu, serta kurangnya pengawasan dari orang tua". (wawancara dengan Anahar Rula 22 Mei 2017)

Sementara faktor-faktor yang menyebabkan anak melakukan tindak pidana kekerasan[8]:

1) Faktor internal.

Remaja yang terlibat perkelahian biasanya kurang mampu melakukan adaptasi pada situasi lingkungan yang kompleks. Kompleks di sini berarti adanya keanekaragaman pandangan, budaya, tingkat ekonomi, dan semua rangsang dari lingkungan yang makin lama makin beragam dan banyak. Situasi ini biasanya menimbulkan tekanan pada setiap orang. Tapi pada remaja yang terlibat perkelahian, mereka kurang mampu untuk mengatasi, apalagi memanfaatkan situasi itu untuk pengembangan dirinya. Mereka biasanya mudah putus asa, cepat melarikan diri dari masalah, menyalahkan orang / pihak lain pada setiap masalahnya, dan memilih menggunakan cara tersingkat untuk memecahkan masalah. Pada remaja yang sering berkelahi, ditemukan bahwa mereka mengalami konflik batin, mudah frustrasi, memiliki emosi yang labil, tidak peka terhadap perasaan orang lain, dan memiliki perasaan rendah diri yang kuat. Mereka biasanya sangat membutuhkan pengakuan.

2) Faktor keluarga

Rumah tangga yang dipenuhi kekerasan (entah antar orang tua atau pada anaknya) jelas berdampak pada anak. Anak, ketika meningkat remaja, belajar bahwa kekerasan adalah bagian dari dirinya, sehingga adalah hal yang wajar kalau ia melakukan kekerasan pula. Sebaliknya, orang tua yang terlalu melindungi anaknya, ketika remaja akan tumbuh sebagai individu yang tidak mandiri dan tidak berani mengembangkan identitasnya yang unik. Begitu bergabung dengan teman-temannya, ia akan menyerahkan dirnya secara total terhadap kelompoknya sebagai bagian dari identitas yang dibangunnya.

\section{3) Faktor sekolah}

Sekolah pertama-tama bukan dipandang sebagai lembaga yang harus mendidik siswanya menjadi sesuatu. Tetapi sekolah terlebih dahulu harus dinilai dari kualitas pengajarannya. Karena itu, lingkungan sekolah yang tidak merangsang siswanya untuk belajar (misalnya suasana kelas yang monoton, peraturan yang tidak relevan dengan pengajaran, tidak adanya fasilitas praktikum, dsb.) akan menyebabkan siswa lebih senang melakukan kegiatan di luar sekolah bersama teman-temannya. Baru setelah itu masalah pendidikan, di mana guru jelas memainkan peranan paling penting. Sayangnya guru lebih berperan sebagai penghukum dan pelaksana aturan, serta sebagai tokoh otoriter yang sebenarnya juga menggunakan cara kekerasan (walau dalam bentuk berbeda) dalam "mendidik" siswanya.

4) Faktor lingkungan

Lingkungan di antara rumah dan sekolah yang sehari-hari remaja alami, juga membawa dampak terhadap munculnya perkelahian. Misalnya lingkungan rumah yang sempit dan kumuh, dan anggota lingkungan yang berperilaku buruk (misalnya narkoba). Begitu pula sarana transportasi umum yang sering menomor-sekiankan pelajar. Juga lingkungan kota (bisa negara) yang penuh kekerasan. Semuanya itu dapat merangsang remaja untuk belajar sesuatu dari lingkungannya, dan kemudian reaksi emosional yang berkembang mendukung untuk munculnya perilaku berkelahi

3. Kendala Yang Dihadapi Kepolisian dalan Menangani Masalah Tindak Pidana Kekerasan yang dilakukan oleh Pelajar di Dompu.

Dalam melakukan upaya pencegahan dan penanggulangan tindak pidana kekerasan yang dilakukan oleh palajar Kepolisian Resort Dompu mengalami beberapa kendala yang sibebakan karena beberapa faktor antara lain :

a. Pelaku Bungkam.

Dengan status tersangka yang seorang pelajar dan jelas masih di bawah umur para penyidik tidak bisa melakukan penyidikan yang sama halnya seperti penyidikan terhadap orang dewasa, karena tersangka belum siap untuk berurusan dengan masalah yang masuk dalam ranah hukum, sehingga dia akan selalu menutup diri dan cenderung bungkam pada saat pelaksanaan penyidikan.

b. Balai Pemasyarakatan (BAPAS).

Pada tingkat pemeriksaan dan penelitian terhadap tersangka anak oleh BAPAS sering mengalami keterlambatan, jadi hasilnya pun sering terlambat diterima oleh Penyidik Polresta Padang. Di dalam Undang-undang sendiri baik oleh KUHAP maupun UT Pengadilan Anak memang tidak diatur kapan batas waktu lamanya pemeriksaan dan penelitian yang dilakukan oleh pihak BAPAS terhadap tersangka anak, pihak BAPAS tidak memilikiacuan pasti tentang berapa lamanya. melakukan penelitian terhadap tersangka anak. Jadi dengan kata lain pihak BAPAS mengacu hanya pada lamanya masa penahanan tersangka anak oleh pihak penyidik kepolisian.

c. OrangTua. 
Penyidik/penyidik pembantu terkadang mendapatkan kendala dalam pelaksanaan penyidikan karena orang tua tersangka yang enggan untuk memberi keterangan dan mendampingi anak dalam proses penyidikan. Orang tua dari tersangka tindak pidana anak biasanya takut dan malu untuk mendampingi anaknya dalam pelaksanaan penyidikan sehingga penyidik tidak bisa melakukan penyidikan terhadap tersangka karena dalam penyidikan terhadap tersangka anak harus didampingi oleh orang tuanya. (wawancara dengan Bapak Daniel AKP Simonguncong 25 mei 2017)

Dapat disimpulkan kendala yang diahadapi oleh Kepolisian dalam menangani tindak pidana kekerasan yang dilakukan oleh pelajar di dompu, yaitu dimana anak yang melakukan tindak pidana tidak mau memberikan penjelasan kenapa dia melakukan tindak pidana,serta tidak adanya Balai Pemasyarakatan di Dompu sehinnga memperlambat proses penyelidikan,serta orang tua yang tidak mau mendampingi anaknya saat proses penyelidikan dilakukan karena merasa malu maupun marah, kecewa kepada anaknya.

\section{SIMPULAN DAN SARAN}

Hasil penelitian menunjukkan bahwa upaya-upaya kepolisian Resort Dompu dalam menanggulangi tindak pidana kekerasan yang dilakukan oleh pelajar di Kabupaten Dompu melakukan, Pertama, Upaya Preemtif, berupa pembinaan pelajar melalui jalur pembina upacara, ceramah, diskusi dan penyuluhan tentang tindak pidana kekerasan, dan upaya preemtif adalah pencegahan yang dilakukan secara dini dengan melakukan penyuluhan disekolah, kantor desa secara khusus kepada anak pelajar dan remaja tentang bahaya melakukan tindak pidana kekerasan.

Kedua, upaya Preventif. Upaya ini yakni pencegahan dengan cara koordinasi lintas sektoral untuk mengawasi pelajar yang terlihat di luar sekolah pada saat jam pelajaran, di lingkungan masyarakat serta melakukan pemeriksaan senjata tajam. Upaya preventif merupakan upaya pencgahan oleh pihak kepolisian dengan melakukan patroli, pengawasan dan rajia diberbagai temapt, serta menyelenggarakan operasi Kepolisian Mandiri kewilayah dengan sandi Operasi yang mengedapanan cara bertindak represif dan preemtif dalam rangka pembrantasan terhadap tindak pidana kekerasan yang dilakukan oleh pelajar.

Ketiga, upaya Represif. Penindakan secara hukum (diproses), dan diberikan tindakan-tindakan tertentu.Tindakan represif tidak selalu dilakukan penahanan atau melaksanakan proses penyidikan. Tetapi juga dapat dengan memberikan tindakan seperti membuat surat pernyataan atau dengan tindakan hukuman seperti membotaki rambut pelajar yang melakukan tindak pidana kekersan. Akan tetapi apabila tindak pidana kekerasan oleh pelajar sudah mengarah kepada tindak pidana kekerasan dengan penganiayaan, maka Kepolisian Resort Dompu akan melakukan proses penyidikan terhadap pelaku tindak pidana kekerasan tersebut.

Kendala yang di hadapi kepolisian Resort Dompu dalam menangani masalah tindak pidana kekerasan yang dilakukan oleh pelajar karena pelaku bungkam, proses persidangan yang terlambat dari BAPAS, orang tua tersangka yang enggan untuk memberi keterangan dan mendampingi anak dalam proses penyidikan.

Mengingat pentingnya pencegahan ini, maka disarankan pada pemerintah harus berperan aktif khusunya Pemerintah Daerah Kabupaten Dompu untuk memberikan dukungan baik berupa moral dan materil dalam upaya menanggulangi tindak pidana kekerasan yang dilakukan oleh pelajar di Kabupaten Dompu. Kemudian bagi penegak hukum khususnya Pihak Kepolisian Resort Dompu harus dapat mengupayakan kerjasama yang serius dengan Instansi-instansi lain yang terkait dalam Upaya menanggulangi tindak pidana kekerasan yang dilakukan oleh pelajar di Kabupaten Dompu. Orang Tua dalam hal menghadapi anak yang melakukan tindak pidana kekerasan harus dapat menjadi pendamping yang aktif serta harus terbuka kepada aparat penegak hukum untuk memberikan keterangan yang jelas dan rinci tentang anak yang melakukan tindak pidana kekerasan. Dan Masyarakat dalam hal ini pihak Desa maupun tokoh-tokoh masyarakat dapat memberikan sumbangan nasehat kepada anak yang melakukan tindak pidana kekerasan yang dilakukan oleh pelajar.

\section{UCAPAN TERIMA KASIH}

Penulis mengucapkan terima kasih kepada editor yang senantiasa memberikan saran dan masukan kepada penulis sehingga artikel ilimiah ini selesai dengan baik.

\section{DAFTAR RUJUKAN}

[1] M. Muhammad, “Aspek Perlindungan Anak dalam Tindak Kekerasan (Bullying) terhadap Siswa Korban Kekerasan di Sekolah (Studi Kasus di Smk Kabupaten Banyumas)," $J$. Din. Huk., vol. 9, no. 3, pp. 268-274, 2009.

[2] U. Nomor, "Tahun 2002 tentang Kepolisian Negara Republik Indonesia," LN Nomor, vol. 2, $2 \mathrm{AD}$.

[3] S. Faisal, Penelitian Kualitatif: Dasar-dasar dan aplikasi. YA3, 1990.

[4] P. Sugiyono, Metode Penelitian Kuantitatif, Kualitatif, dan R\&D. 2013.

[5] K. G. Esterberg, "Qualitative methods in social research," 2002.

[6] A. Suharsimi, "Prosedur penelitian suatu pendekatan praktik," Jakarta: Rineka Cipta, 2006.

[7] B. N. Arief, Masalah penegakan hukum dan kebijakan hukum pidana dalam penanggulangan kejahatan. Kencana Prenada Media Group, 2007.

[8] A. Wahid, M. Irfan, and M. T. Hasan, Perlindungan terhadap korban kekerasan seksual: advokasi atas hak asasi perempuan. Refika Aditama, 2001. 